\title{
Genetic Differentiation of Jack Pine (Pinus banksiana) and Red Pine (P. resinosa) Populations From Metal Contaminated Areas in Northern Ontario (Canada) Using ISSR Markers
}

\author{
By M. RangeR ${ }^{1)}$, K. K. Nkongolo ${ }^{\left.1),{ }^{*}\right)}$, P. Michael ${ }^{1)}$ and P. BecketT ${ }^{1)}$
}

(Received 27 ${ }^{\text {th }}$ August 2007)

\begin{abstract}
Metal accumulation in soil and plant tissues has caused severe ecological damage in forest ecosystems in the Sudbury region. The main objective of the present study was to determine the levels of genetic diversity in jack and red pine populations growing in metal contaminated and uncontaminated areas. Newly introduced populations were compared to 40 to 60 old populations. For jack pine, the percentage of polymorphic loci (P \%) ranged from $14.6 \%$ to $45.8 \%$ with a mean of $31.6 \%$. Nei's gene diversity (h) varied from 0.046 to 0.169 with an average of 0.100 , and Shannon's index (I) ranged from 0.070 to 0.250 with an average of 0.153 . The level of genetic variation was much lower in the red pine populations. For this species, the level of polymorphic loci varied from $4.55 \%$ to $27.27 \%$. The mean for Nei's gene diversity and Shannon's information index, were 0.034 and 0.053 , respectively. The highest genetic diversity values were observed in new plantations being developed by the Sudbury reforestation program. Overall, the genetic distance among the Pinus banksiana populations revealed that all the populations analyzed were genetically close to each other. There was no association between metal accumulation and genetic diversity for both species.
\end{abstract}

Key words: Jack pine, red pine, ISSR, genetic diversity, metal contamination, Sudbury.

\section{Introduction}

The genus Pinus, belonging to the Pinaceae family, consists of over 100 species which makes it the largest genus of conifers, as well as, the most widespread in the Northern Hemisphere (VIDAKOVIC, 1991). Its distribution ranges from the arctic and subarctic south to Guatemala, North Africa and Indonesia. Pines inhabit the boreal, as well as, temperate and mountainous tropical regions (VIDAKOVIC, 1991).

In Ontario (Canada), Crown forest accounts for approximately $91 \%$ of forested land. Most of this land is located in the Northern region and represents the boreal and the Great Lake St. Lawrence Forests composed mainly of conifer species (OMNR, 2001). Studies have provided information on landscape degradation, soil toxicity, acidification, plant metal accumulation and forest composition in Northern Ontario but knowledge of genetic variation within and among forest tree populations is limited.

\footnotetext{
1) Department of Biology, Laurentian University, Sudbury, Ontario, P3E 2C6, Canada.

*) Corresponding author: knkongolo@laurentian.ca
}

Several authors have reported differences between subsets of tolerant and sensitive plants growing in contaminated areas (MÜlLER-STARCK, 1989; SCHOLZ and Bergmann, 1984). Enzymatic studies of Norway spruce revealed genetic differences between groups of sensitive trees in polluted areas (ScHOLZ and BERGMANN, 1984). It has been demonstrated that the evolution of heavymetal tolerant ecotypes occurs at an unexpectedly rapid rate (Wu et al., 1975), and that despite founder effect and selection, in several cases, the recently established tolerant-populations maintain a high level of variation and appear to be at least as variable as non-tolerant populations. Observations of higher heterozygosity in tolerant plants of European beech in Germany (MÜLLERSTARCK, 1989), scots pine in Germany and Great Britain (GEBUREK et al., 1987) and trembling aspen and red maple in the United States (BERRANG et al., 1986) have been reported. Several authors, however, have considered bottleneck effects as main factors in low genetic variation in some species such as Deschampsia cespitosa, Pinus monticola, and Lychnis alpina (BusH and BARETT, 1993; NoRDAL et al., 1999; Steonhoff et al., 1983). MiJNATOWICZ (1983) presented evidence of loss of genes and heterozygosity in tolerant Scots pines.

The main objective of the present study was to determine the levels of genetic diversity in jack and red pine populations growing in metal contaminated and uncontaminated areas using ISSR. The sustainability of these populations is also discussed.

\section{Material and Methods}

\section{Genetic material}

For the genetic variation study, needle samples were collected from eleven jack pine and seven red pine populations from Northern Ontario (Fig. 1). For each population, 15 trees (5 to 10\%) were surveyed. About $5 \mathrm{~g}$ of needles were frozen in liquid nitrogen and stored at $-80^{\circ} \mathrm{C}$ until use for DNA extraction.

\section{Site characterization}

Soils, needles and branch samples from the selected sites have been already analyzed in a previous study for concentrations of metals including aluminum, arsenic, cadmium, cobalt, copper, lead, manganese, magnesium, nickel, and zinc (FREEDMAN and HUTCHINSON, 1980; GRATTON et al., 2000). High levels of metal contents in soils and vegetation have been documented within short distances of the smelters in Sudbury compared to control sites (FREEDMAN and HUTCHINSON, 1980; GRATTON et al., 2000). The highest levels of metal accumulation in 


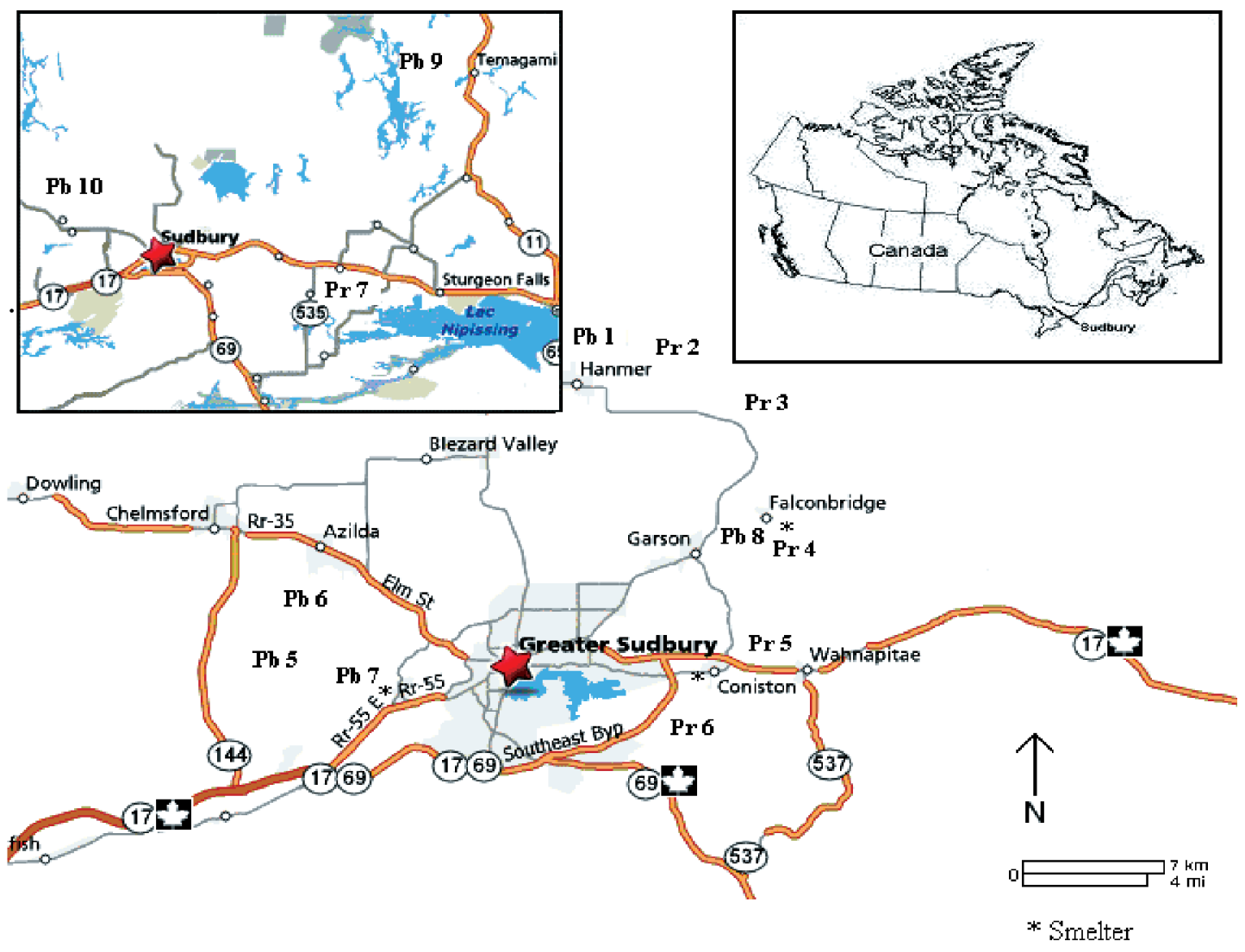

Figure 1. - Locations of jack pine (sites 4 to 11) and red pine (sites A to G) sampling sites within the Greater Sudbury region. Site 4 represents Inco 1; site 5, Inco 2; site 6, Falconbridge 1; site 7, Falconbridge 2; site 8, Falconbridge 3; site 9, Inco Tailing; site 10, Low Water Lake (control); and site 11 - Temagami (control). Site A represents Falconbridge A; site B Falconbridge B; site C, Falconbridge C; site D, Coniston; E, Daisy Lake; and F, Verner.

soil and plant tissues were detected in samples from populations within the vicinity of Falconbridge and INCO Smelters in Sudbury (FREEDMAN and HUTCHINSON, 1980; GRATTON et al., 2000).

\section{DNA extraction}

The total cellular DNA from $1 \mathrm{~g}$ of individual samples was extracted from needles using the method described by NkONGOLO (1999), with some modifications. The concentration of each sample was determined using the DNA quantitation kit from Bio-Rad and the purity was determined using a spectrophotometer (Varian Cary 100 UV-VIS spectrophotometer).

\section{Amplification of ISSR markers}

Twenty ISSR primers, synthesized by Invitrogen, were chosen for preliminary amplification of four populations from Pinus banksiana. DNA amplification was performed following the procedure described by NAGAOKA and OGIHARA (1997) and NKONGOLO et al. (2005) with some modifications. Each PCR reaction was performed in a $25 \mu \mathrm{l}$ volume containing $5 \mathrm{ng}$ of genomic plant DNA, $10 \mathrm{mM}$ Tris-HCl, pH 8.3 [at $25^{\circ} \mathrm{C}$ ]; $50 \mathrm{mM} \mathrm{KCl}$; Applied Biosystems, Foster City, CA), $3.5 \mathrm{mM} \mathrm{MgCl}_{2}, 200 \mu \mathrm{M}$ of each dNTP (Applied Biosystems, Foster City, CA), $0.5 \mu \mathrm{M}$ primer and $0.625 \mathrm{U}$ of Taq DNA polymerase (Applied Biosystems, Foster City, Calif.). For each primer, a negative control reaction with double distilled water was included. A drop of mineral oil was added to each reaction and the samples were amplified on a DNA thermal cycler (Perkin Elmer, Foster City, CA). The cycles performed were as follows: an initial denaturation at $95^{\circ} \mathrm{C}$ for 5 minutes followed by a 2 minute incubation at $85^{\circ} \mathrm{C}$ at which point the polymerase was added; 42 cycles of 90 second at $95^{\circ} \mathrm{C}, 2$ minute at $55 \mathrm{oC}$ and 60 seconds at $72^{\circ} \mathrm{C}$ were performed; a final extension at $72{ }^{\circ} \mathrm{C}$ for 7 minutes and a subsequent incubation at $4 \mathrm{oC}$ followed. PCR products were loaded onto $1 \%$ agarose gels (invitrogen) in 0.5 X Tris-borate-EDTA (TBE) buffer containing ethidium bromide and run at $2.8 \mathrm{~V} / \mathrm{cm}$ for 90 minutes. The agarose gels were documented using the Bio-Rad ChemiDoc XRS system and analyzed with the Discovery Series Quantity One 1 D Analysis Software.

\section{ISSR analysis}

Only the ISSR primers which gave consistent profiles across the populations were selected. The presence and absence of bands were scored as 1 or 0 respectively. Faint bands were not recorded for analysis. The following parameters were generated using POPGENE 1.31 to describe genetic variation: the percentage of polymorphic loci (P), Nei's gene diversity (h), Shannon's information index (i), the observed number of alleles (Na) and the effective number of alleles (Ne) (NEI, 1973; YEH et 
al., 1997). The genetic structure was investigated using Nei's gene diversity statistics, including the total genetic diversity $(\mathrm{Ht})$, genetic diversity within populations $(\mathrm{Hs})$, and the relative magnitude of genetic differentiation among populations. Jaccard's similarity coefficients were generated to determine the genetic distances among populations using RAPDistance Program version 1.04 (ARMSTRONG et al., 1994). Dendrograms were constructed using the neighbour-joining analysis. This method starts with a starlike tree with no hierarchical structure and in a stepwise fashion finds the two operational taxonomic units that minimize the total branch length at each cycle of clustering. The unrooted tree generated by the Neighbor joining method is constructed under the principle of minimum evolution (SAITOU and NEI, 1987).

\section{Results}

\section{ISSR markers}

ISSR primers were used to determine genetic variation between and within Pinus banksiana and $P$. resinosa. Seven of the 20 ISSR primers screened amplified DNA samples from all populations studied (Table 1). Figures 2 and 3 illustrate ISSR profiles of Jack and red pines, respectively, using primer 1789B.

\section{Genetic variation within populations}

For Jack pine, a low to moderate levels of genetic variation was revealed within each population. The percentage of polymorphic loci $(\mathrm{P} \%)$ ranged from $14.60 \%$ to $45.80 \%$ with a mean of $31.60 \%$. The mean level of polymorphism for the eight populations from the greater Sudbury area was $27.60 \%$ while this value was higher for populations from the nurseries with an average of $42.40 \%$ detected polymorphic loci. The levels of genetic variation detected in populations from metal-contaminated areas were similar to those found in control sites. The Nei's gene diversity (h) for all jack pine populations analyzed varied from 0.046 to 0.169 with an average of 0.100 , and Shannon's index (I) ranged from 0.070 to 0.250 with an average of 0.153 . The mean observed number of alleles $(\mathrm{Na})$ ranged from 1.146 to 1.458 , while the mean effective number of alleles $(\mathrm{Ne})$ varied from 1.107 to 1.310 (Table 2).

The level of genetic variation was much lower in the red pine populations. For this species, the level of polymorphic loci varied from $4.55 \%$ to $27.27 \%$ (Table 3 ). The mean level of polymorphic loci for populations from the greater Sudbury region excluding the population from the nursery was only $8.3 \%$. Like in jack pine populations, the polymorphism detected in contaminated popu-

Table 1. - Invitrogen 3' anchored ISSR primers used to generate multilocus profiles with DNA from jack pine and red pine bulk samples.

\begin{tabular}{lll}
\hline $\begin{array}{l}\text { ISSR } \\
\text { primer }\end{array}$ & Nucleotide sequence $\left(5^{\prime} \rightarrow 3^{\prime}\right)$ & Fragment size range (bp) \\
\hline 17 898B & CAC ACA CAC ACA GT & $300-2000$ \\
SC ISSR 5 & ACG ACG ACG ACG AC & $300-3000$ \\
SC ISSR 9 & GATC GATC GATC GC & $200-4000$ \\
UBC 809 & AG AG AG AG AG AG AG AG G & $300-1000$ \\
UBC 825 & ACA CAC ACA CAC ACA CT & $500-4000$ \\
UBC 844 & CTC TCT CTC TCT CTC TRC & $300-2000$ \\
\hline
\end{tabular}

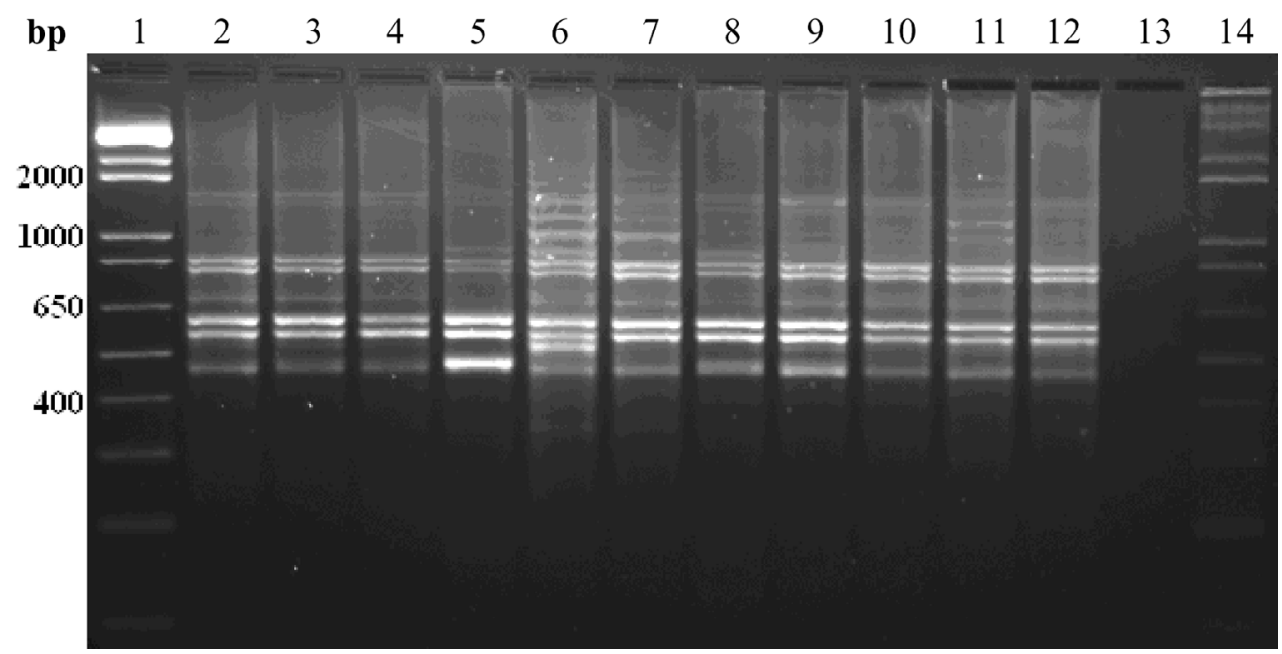

Figure 2. - PCR amplification of jack pine genomic DNA using ISSR primer 17898B. Lanes 1 and 14 contain $1 \mathrm{~kb}$ + Ladder; Lanes 2 to 12 contain amplified products from different populations; lane 2 - Boréal Nursery; Lane 3 - Land Reclamation Nursery; Lane 4 - Inco Nursery; Lane 5 - Inco 1; Lane 6 - Inco 2; Lane 7 - Falconbridge 1; Lane 8 - Falconbridge 2; Lane 9 - Falconbridge 3; Lane 10 - Inco Tailing; Lane 11 - Temagami (control); Lane 12 - Low Water Lake (control); Lane 13 - Blank. 
lations was similar to that found in non contaminated site used as a control. Overall, the mean for Nei's gene diversity and Shannon's information index, were 0.034 and 0.053 , respectively for all the red pine populations

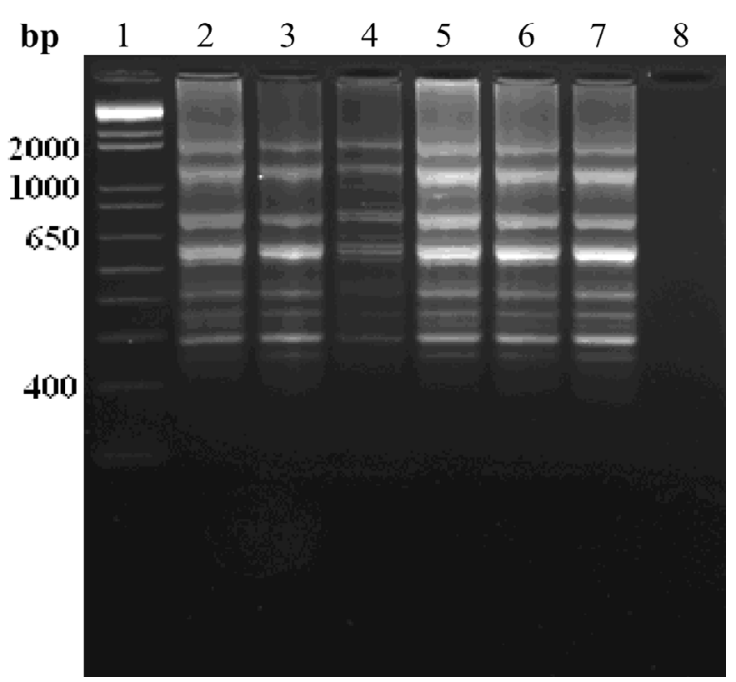

Figure 3. - PCR amplification of red pine genomic DNA using ISSR primer 17898B. Lanes 2 to 12 contain amplified products from different populations. Lane 1 contains $1 \mathrm{~kb}+$ Ladder; Lane 2, Falconbridge A; Lane 3, Falconbridge B; Lane 4, Falconbridge C; Lane 5, Coniston; Lane 6, Daisy Lake; Lane 7, Verner (control); Lane 8 - Blank. analyzed. The mean observed number of alleles $(\mathrm{Na})$ ranged from 1.045 to 1.270 while the mean effective alleles (Ne) varied from 1.00 to 1.17 (Table 3). The highest genetic diversity values were observed in the populations used for the Sudbury reforestation program. High levels of metal content did not affect the level variation for both species.

\section{Genetic differentiation among populations}

For jack pine, the mean gene diversity within populations $(\mathrm{Hs})$ and the total gene diversity $(\mathrm{Ht})$ were 0.100 and 0.144 , respectively. The variation among populations (Gst) were 0.304 indicating that $30.40 \%$ of total genetic diversity were attributed to the differences among populations. The observed structure of genetic variability shows that there is a sensitive level of differentiation among the jack pine populations in the target regions. The overall rate of gene flow $(\mathrm{Nm})$ among populations was 1.14. For red pine the $\mathrm{Hs}$ and $\mathrm{HT}$ values were 0.034 and 0.044 , respectively. About $22 \%$ of the total genetic diversity in red pines was attributed to differences among populations.

\section{Genetic relatedness}

Because of the monomorphic nature in many red pine ISSR profiles, the genetic relationships among populations couldn't be established for that species. Therefore,

Table 2. - Genetic variability parameters of Pinus banksiana populations growing in the Sudbury area based on ISSR data.

\begin{tabular}{llllll}
\hline Populations & $\mathrm{P}(\%)$ & $\mathrm{h}$ & $\mathrm{I}$ & $\mathrm{Ne}$ & $\mathrm{Na}$ \\
\hline Nursery 1 (Introduction 1) & 39.58 & 0.0961 & 0.1535 & 1.1579 & 1.3958 \\
Nursery 2 (Introduction 2) & 41.67 & 0.1380 & 0.2106 & 1.2248 & 1.4167 \\
Nursery 3 (Introduction 3) & 45.83 & 0.1687 & 0.2501 & 1.2946 & 1.4583 \\
Inco 1 & 31.25 & 0.1120 & 0.1653 & 1.2035 & $\mathbf{1 . 3 1 2 5}$ \\
Inco 2 & 31.25 & 0.1171 & 0.1727 & 1.2061 & 1.3125 \\
Falconbridge 1 & 14.58 & 0.0456 & 0.0701 & 1.0756 & 1.1458 \\
Falconbridge 2 & 27.08 & 0.0995 & 0.1467 & 1.1758 & 1.2708 \\
Falconbridge 3 & 20.83 & 0.0630 & 0.0982 & 1.1004 & 1.2083 \\
Inco Tailing & 35.42 & 0.0977 & 0.1552 & 1.1514 & 1.3542 \\
Temagami (control) & 29.17 & 0.0818 & 0.1284 & 1.1310 & 1.2917 \\
Low Water Lake (control) & 31.25 & 0.0812 & 0.1297 & 1.1256 & 1.3125 \\
\hline MEAN & 31.63 & 0.1001 & 0.1528 & 1.1679 & 1.3163 \\
\hline
\end{tabular}

$\mathrm{P}$, represents percentage of polymorphic loci; h, Nei's gene diversity; I, Shannon's information index; $\mathrm{Ne}$, effective number of alleles; $\mathrm{Na}$, observed number of alleles.

Table 3. - Genetic variability parameters of Pinus resinosa populations growing in the Sudbury area based on ISSR data.

\begin{tabular}{llllll}
\hline Population & $\mathrm{P}(\%)$ & $\mathrm{h}$ & $\mathrm{I}$ & $\mathrm{Ne}$ & $\mathrm{Na}$ \\
\hline Near Falconbridge & 4.55 & 0.0044 & 0.0092 & 1.0049 & 1.0455 \\
Very near Falconbridge & 13.64 & 0.0411 & 0.0638 & 1.0672 & 1.1364 \\
Falconbridge & 4.55 & 0.0226 & 0.0314 & 1.0450 & 1.0455 \\
Coniston & 9.09 & 0.0180 & 0.0309 & 1.0244 & 1.0909 \\
Daisy Lake & 9.09 & 0.0272 & 0.0433 & 1.0389 & 1.0909 \\
Verner (control) & 9.09 & 0.0267 & 0.0423 & 1.0398 & 1.0909 \\
Introduction 1 (control) & 27.27 & 0.0988 & 0.1465 & 1.1710 & 1.2727 \\
\hline MEAN & 11.04 & 0.0341 & 0.0525 & 1.0559 & 1.1104 \\
\hline
\end{tabular}

P, represents percentage of polymorphic loci; h, Nei's gene diversity; I, Shannon's information index; $\mathrm{Ne}$, effective number of alleles; and $\mathrm{Na}$, observed number of alleles. 
the genetic relatedness was analyzed only for jack pine populations. The Jaccard similarity coefficients and genetic distance were calculated using ISSR data. The genetic distance scale runs from 0 (identical) to 1 (different for all criteria). In general, the genetic distance values were low as they ranged from 0.037 to 0.365 (Table 4). Overall the genetic distance values revealed that all the eleven jack pine populations were genetically closely related (Table 4). The two populations from control site (uncontaminated), Low Water Lake and Temagami were the most closely related. The largest genetic distance was observed between population 5 from INCO 2 and the new population used in 2006 for reclamation (called introduction 2 in the present study). The dendrogram constructed, based on ISSR data revealed a particular clustering (Fig. 4). All the populations from the greater Sudbury that we analyzed clustered together while the three newly introduced populations from nurseries were grouped in a separate cluster (Fig. 4). The patristic distances based on the neighbor-joining $(\mathrm{NJ})$ analysis were estimated.

\section{Discussion}

Loss of rare alleles, lower heterozygosity and directional selection have been concerns of plant population (BERGMANN and Scholz, 1989). Most of the forest ecosystems within the Sudbury area have improved considerably during the last 30 years (DuDKA et al., 1995; GRATTON et al., 2000). Vascular and nonvascular plants such as conifers, birches and lichens have re-invaded semi-barren landscapes. More than seven million trees, mostly conifers, have been planted in the Greater Sudbury Region. Genetic diversity is the foundation for forest sustainability and ecosystem stability. Bench marking genetic diversity in forest tree populations can provide resource managers with an indicator of longterm forest sustainability and ecosystem health (MOSSEler and RAJORA, 1998; RAJORA and MOSSELER, 2001a, 2001b).

In the present study, jack pine and red pine populations from contaminated and uncontaminated sites were analyzed using ISSR markers. These populations were

Table 4. - Distance matrix generated using bulk sample analysis from various populations of jack pine ISSR data (RAPDistance version 1.04).

\begin{tabular}{llllll}
\hline Populations & $\mathrm{P}(\%)$ & $\mathrm{h}$ & $\mathrm{I}$ & $\mathrm{Ne}$ & $\mathrm{Na}$ \\
\hline Nursery 1 (Introduction 1) & 39.58 & 0.0961 & 0.1535 & 1.1579 & 1.3958 \\
Nursery 2 (Introduction 2) & 41.67 & 0.1380 & 0.2106 & 1.2248 & 1.4167 \\
Nursery 3 (Introduction 3) & 45.83 & 0.1687 & 0.2501 & 1.2946 & 1.4583 \\
Inco 1 & 31.25 & 0.1120 & 0.1653 & 1.2035 & $\mathbf{1 . 3 1 2 5}$ \\
Inco 2 & 31.25 & 0.1171 & 0.1727 & 1.2061 & $\mathbf{1 . 3 1 2 5}$ \\
Falconbridge 1 & 14.58 & 0.0456 & 0.0701 & 1.0756 & 1.1458 \\
Falconbridge 2 & 27.08 & 0.0995 & 0.1467 & 1.1758 & $\mathbf{1 . 2 7 0 8}$ \\
Falconbridge 3 & 20.83 & 0.0630 & 0.0982 & 1.1004 & $\mathbf{1 . 2 0 8 3}$ \\
Inco Tailing & 35.42 & 0.0977 & 0.1552 & 1.1514 & 1.3542 \\
Temagami (control) & 29.17 & 0.0818 & 0.1284 & 1.1310 & $\mathbf{1 . 2 9 1 7}$ \\
Low Water Lake (control) & 31.25 & 0.0812 & 0.1297 & 1.1256 & 1.3125 \\
\hline MEAN & 31.63 & 0.1001 & 0.1528 & 1.1679 & 1.3163 \\
\hline
\end{tabular}

1 , represents introduction 1; 2, Introduction 2; 3, Introduction 3; 4, Inco 1 site; 5 , Inco 2 site ; 6 , Falconbridge 1 site; 7, Falconbridge 2 site; 8, Falconbridge 3 site; 9, Inco Tailing; 10, Temagami site; and 11, Low Water Lake site.

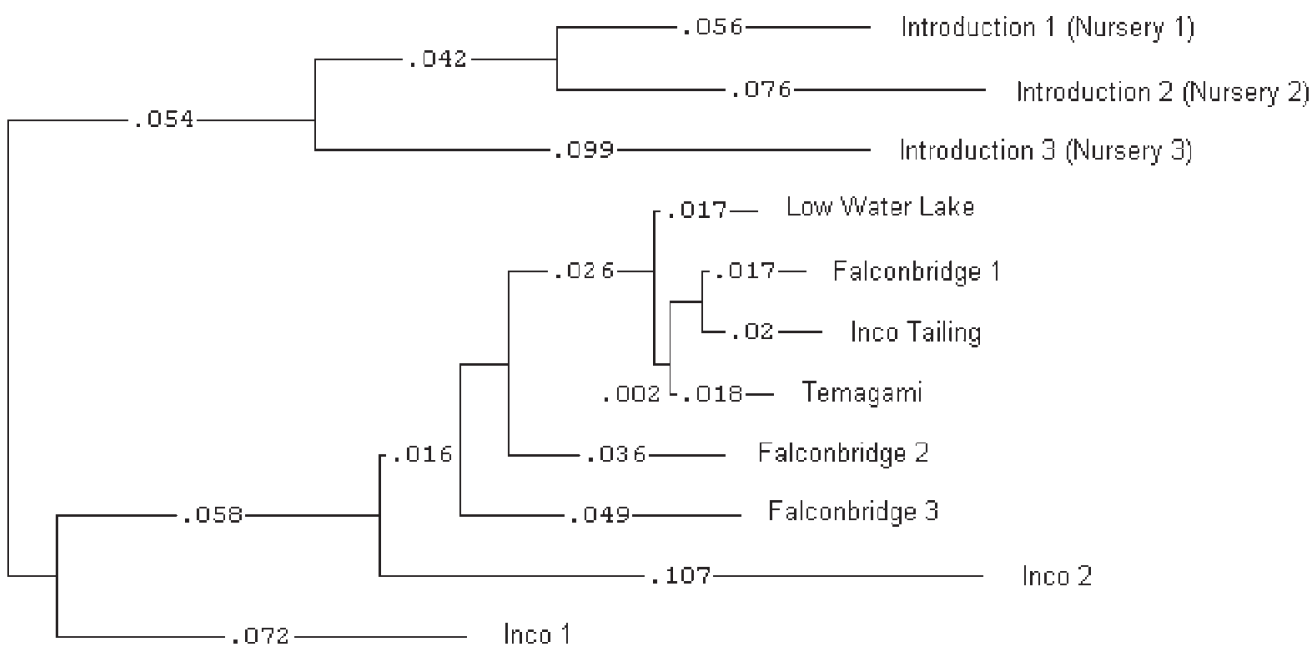

Figure 4. - Dendrogram of the genetic relationships among eleven populations of jack pine based on Jaccard similarity matrix using ISSR data. The values above the branches indicate the patristic distances based on the neighbor-joining (NJ) analysis. 
compared to new populations used for restoration. The estimates of population differentiation (Gst) for jack pine and red pine showed that more than $30 \%$ for jack pine and $20 \%$ for red pine of total genetic variation is among populations and the remainder resides within populations. These estimates are among the highest obtained for Pinus species as cited by LEDIG (1998). YE et al. (2002) reported a Gst of $15.5 \%$ for jack pine and $16.2 \%$ for lodgepole pine based on RAPD markers. Other studies reported Gst of $32 \%$, and for P. cembra, $22 \%$ for P. ayacahuite, and P. muricata (LEDIG, 1998). Microsatellite analysis of red pine populations distributed throughout the natural range of this species revealed a high population differentiation with 28-35\% of genetic variation partitioned among populations (Boys et al., 2005). Several studies showed that the Gst values for most pine species studies including lodgepole and jack pines were usually less than $10 \%$ and often less than 5\% (LEDIG, 1998).

The high genetic differentiation among populations in red and jack pines compared to other conifer species could be attributable to a high rate of selfing in these populations, because predominantly selfing plant populations tend to show higher population differentiation than outcrossing ones (LOVELESS and HAMRICK, 1984; HAMRICK and GODT, 1990)

In general, the low genetic variation in red pine populations from the Sudbury basin is consistent with other studies from other regions. This contrasts strikingly with the high genetic variability found in other conifer (HAMRICK and GODT, 1990). In fact detailed genetic characterizations of black and red spruce populations from Ontario (including the Sudbury region), Quebec and the Atlantic provinces revealed a very high level of polymorphic loci (over 80\%) and genetic diversity (DoBRZENICKA et al., 2007, unpublished data; NKONGOLO et al., 2003).

The genetic uniformity in red pine has been ascribed to genetic bottleneck during the last glaciations (FOWLER and Morris, 1977; WALter and EPPERson, 2005). The highly fragmented population structure and self-compatible mating system may also have contributed to the loss of genetic variation through inbreeding and genetic drift during the post-glacial expansion from the refugia (FowLER, 1964 and 1965).

Evolution of jack pine in North America could has possibly followed the same pattern of red pine which despite increases in population numbers and mutations has produced only low genetic variation specially at the nuclear level. The most plausible explanation of this low variability is bottleneck due to the last glaciations. The entire area of the present-day distribution of jack pine is thought to have been covered by ice during the last glacial stages. Geological and paleobotanical evidences from fossil pollen depositions indicate that jack pine survived glaciations in an extensive refugium centred on the Appalachian Highlands of Eastern North America (DAUBENMIRE, 1978). Upon recession of the Wisconsin icecap, jack pine north-ward is thought to have happened rapidly (DAUBENMIRE, 1978).

The exposure of red and jack pines to toxic substances for more than 50 years in the Sudbury region did not reduce the level of genetic variation as reported for
Deschampsia cespitosa (NKONGOLO et al., 2007). In fact, among the sites analyzed in the present study, the highest level of metal content in soil and plant tissues were detected in samples from populations located within the vicinity of Falconbridge and INCO Smelters in Sudbury (GRATTON et al., 2000; NKONGOLO et al. 2007). The level of genetic variation in those sites was not significantly different compared to uncontaminated sites within the greater Sudbury region. This clearly indicated that the exposure to metals for more than 50 years has no effect on genetic structure and diversity of pine populations. This was also the case for Deschampsia cespitosa (herbaceous species) populations growing in the greater Sudbury regions. But the analysis of $D$. cespitosa populations growing in metal residues dumping sites in Cobalt with certain metal content of 20 fold than in Sudbury showed significant reduction of the level of genetic variation (NKONGOLO et al., 2007). This suggests that although the levels of metal accumulation in Sudbury soils exceed in some cases the upper limit set by the MEE, it has not reached a threshold level that can be damageable for the genetic makeup of both herbaceous and conifer species. Evidence of loss of genetic diversity at the population level caused by pollution has been demonstrated in some species (LOPES et al., 2004 and VAN StraAlen and Timmermans, 2002). But, plants possess homeostatic cellular mechanisms to regulate the concentration of metal ions inside the cell to minimize the potential damage that could result from the exposure to nonessential metal ions. These mechanisms serve to control the update, accumulation and detoxification of metals (Foy et al., 1978).

The low genetic diversity in jack and red pines with ISSR markers confirms data from other reports using allozymes, RAPD, and microsatellites (Boys et al., 2005; FOWLER and MorRIs, 1977; Mosseler et al., 1991 and 1992). This suggests that regardless of the regions of the genome targeted, red pine is one of the most genetically depauperate conifer species in North America. The sustainability of jack and red pine populations from the Sudbury region is not threatened because of the relatively high level of genetic diversity in newly introduced populations compared to existing populations and to a high genetic differentiation among populations.

\section{Acknowledgements}

We express our appreciation to the Natural Sciences and Engineering Research Council of Canada (NSERC), INCO Limited (Sudbury), and Xtrata plc for financial support.

\section{References}

Armstrong, J. S, A. J. Gibbs, R. Peakall and G. Weiller (1994): The RAPDistance Package.

Bergmann, F. and F. Scholz (1989): Selection effects of air pollution in Norway spruce (Picea abies) populations. In: Scholz, H., Gregorius, R. and Rudin, D. (Editors). Genetic effects of air pollutants in forest tree populations. Springer-Verlag, Berlin. pp. 143-160.

Berrang, P., D. F. Karnosky, R. A. Mickler and J. P. BenNET (1986): Natural selection for ozone tolerance in Populus tremuloides. Can. J. For. Res. 16: 1214-1216. 
Boys, J., C. MARILYN and S. Dayanandan (2005): Microsatellite analysis reveals genetically distinct populations of red pine (Pinus resinosa, Pinaceae). Am. J. Bot. 92: 833-841.

Bush, E. J. and S. C. H. BARETT (1993): Genetics of mine invasion by Deschampsia cespitosa (Poaceae). Can. J. Bot. 71: 1336-1347.

Dudka, S., R. Ponce-Hernandez and T. C. Hutchinson (1995): Current levels of total element concentrations in the surface layers of Sudbury's soils. Sci. Total Environ. 162: $161-171$.

DAubenmiRe, R. (1978): Plant geography. Academic Press, New York. Pp. 338.

FowleR, D. P. (1964): Effects of inbreeding in red pine, Pinus resinosa Ait. I. Factors affecting natural selfing. Silvae Genet. 13: 170-177.

Fowler, D. P. (1965): Effects of inbreeding in red pine, Pinus resinosa Ait. II. Pollination studies. Silvae Genet. 14: $12-23$.

Fowler, D. P. and R. W. MorRIs (1977): Genetic diversity in red pine: evidence for low heterozygosity. Can. J. For. Res. 7: 343-347.

Foy, C. D., R. L. Chaney and M. C. White (1978): The physiology of metal toxicology in plants. Annu Rev Plant Physiol. 29: 11-566.

Freedman, B. and T. C. Hutchinson (1980): Pollutants inputs from atmosphere and accumulations in soils and vegetation near a nickel-copper smelter at Sudbury, Ontario, Canada. Can. J. Bot. 58: 108-131.

Geburek, T., F. Scholz, W. Knabe and A. Vornweg (1987): Genetic studies by isozyme gene loci on tolerance and sensitivity in air polluted Pinus sylvestris field trial. Silvae Genet. 36: 49-53.

Gratton, W. S., K. K. Nkongolo and G. A. Spiers (2000): Heavy metal accumulation in Soil and jack pine (Pinus banksiana) needles in Sudbury, Ontario, Canada. Bull. Environ. Contam. Toxicol. 64: 550-557.

HAMRICK, J. L. and M. J. W. GoDT (1990): Allozyme diversity in plant species. In: Brown, A. H. D., ClEGG, M. T., KAHLER, A. L. and B. S. WeIR (Eds.). Plant population genetics, breeding and genetic resources, pp. 43-63. Sinauer, Sunderland, Massachusetts, USA.

Ledig, F. T. (1998): Genetic variation in Pinus. In: Ecology and biogeography of Pinus. Edited by D. M. Richardson. Cambridge University Press, Cambridge, U.K. pp. 251-280.

LOVELESS, M. D. and J. L. HAMRICK (1984): Ecological determinants of genetic structure of plant populations. Ann. Rev. Ecol. Syst. 15: 65-95.

LOPES, I., D. J. BAIRD and R. RIBEIRo (2004): Genetic determination of tolerance to lethal and sublethal copper concentrations in field populations of Daphnia longispina. Arch. Environ. Contam. Toxicol. 46: 43-51.

MejNARTOWICZ, L. (1983): Changes in genetic structure of Scotch pine (Pinus sylvestris L.) population affected by industrial emission of fluoride and sulphur dioxide. Genet. Polonica 24: 41-50.

Mosseler, A., D. J. InNes and B. A. Roberts (1991): Lack of allozymic variation in disjunct Newfounland populations of red pine (Pinus resinosa). Can. J. For. Res. 21: $525-428$.

Mosseler, A., K. N. EgGer and G. A. Hugues (1992): Low levels of genetic diversity in red pine confirmed by random amplified polymorphic DNA markers. Can. J. For. Res. 22: 1332-1337.

Mosseler, A. and O. P. RAJORA (1998): Monitoring population viability in declining tree species using indicators of genetic diversity and reproductive success. In: SASSA, K. (ed.) Environmental forest science. Kluwer Academic Publishers, Dordrecht, The Netherlands, pp. 333-344.

MülLER-StaRCK, G. (1989): Genetic implications of environmental stress in adult forest stands of Fagus sylvatica L.; pp127-142. In: Scholz, F., GREgorius, H.-R. and Rudin, D. (eds.): Genetic Aspects of Air Pollutants in Forest Tree Populations. Springer Verlag Berlin, Heidelberg, New York, Tokyo.

NAGAOKA, T. and Y. OGIHARA (1973): Applicability of intersimple sequence repeat polymorphisms in wheat for use as DNA markers in comparison to RFLP and RAPD markers. Theor. Appl. Genet. 94: 597-602. (1997).

NEI, M.: Analysis of gene diversity in subdivided populations. Proceedings of the National Academy of Sciences of the USA 70: 3321-3323.

Nkongolo, K. K. (1999): RAPD variations among pure and hybrid populations of Picea mariana, P. rubens and $P$. glauca (Pinaceae) and cytogenetic stability of Picea hybrids: identification of species - specific RAPD markers. Plant Syst. Evol. 215: 229-239.

Nkongolo, K. K., L. Deverno and P. Michael (2003): Genetic validation and characterization of RAPD markers differentiating black and red spruces: molecular certification of spruce trees and hybrids. Plant Syst. Evol. 236: 151-163.

Nkongolo, K. K., P. Michael and T. Demers (2005): Application of ISSR, RAPD, and cytological markers to the certification of Picea mariana, P. glauca and $P$. engelmannii trees, and their putative hybrids. Genome 48: 302-311.

Nkongolo, K. K., M. Mehes, A. Deck and P. Michael (2007): Metal content in soil and genetic variation in Deschampsia cespitosa populations from Northern Ontario (Canada): application of ISSR markers. Eur. J. Genet. Tox.. March issue: 1-38. www.Swan.ac.uk/get/ ejgt/Nkongolo.

Nordal, I., K. B. Haraldsen, A. Ergon and A. B. ERIKSEN (1999): Copper resistance and genetic diversity in Lychnis alpina (Caryophyllaceae) populations on mining sites. Folia Geobotanica 34: 471-481.

ONTARIO MINISTRY OF NATURAL RESOURCES (2001): Critical review of historical and current tree planting progras on private lands in Ontario. pp. 42.

RAJorA, O. P. and A. Mosseler (2001a): Molecular markers in sustainable management, conservation, and restoration of forest genetic resources. In: MÜLLERStARCK, G. and SchuberT, R. (eds) Genetic response of forest systems to changing environmental conditions. Kluwer Academic Publishers, Volume 70, pp. 187-201.

RAJora, O. P. and A. Mosseler (2001b): Challenges and opportunities for conservation of forest genetic resources. Euphytica 118: 197-212.

SAITOU, N. and M. NEI (1987): The neighbor-joining method: A new method for reconstructing phylogenetic trees. Mol. Biol. Evol., 406-425.

Scholz, F. and F. BERGMANN (1984): Selection pressure by air pollution as studied by isozyme gene-systems in Norway spruce exposed to sulphur dioxide. Silvae Genet. 33: 238-241.

SteinhofF, R. J., D. G. Joyce and L. Fins (1983): Isozyme variation in Pinus monticola. Can. J. For. Res. 13: 1122-1132.

VAn StraAlen, N. M. and M. J. T. N. Timmermans (2002): Genetic variation in toxicant-stressed populations: An evaluation of the "genetic erosion" hypothesis. Hum. Ecol. Risk Assess. 8: 983-1002. 
VIDAKOVIC, M. (1991): Conifers morphology and variation, Translated from Croatian by Maja Soljan. Croatia: Graficki Zavod Hrvastske.

WALter, R. and B. K. EPPERSON (2005): Geographic pattern of genetic diversity in Pinus resinosa: contact zone between descendants of glacial refugia. Am. J. Bot. 92: 92-100.

Wu, L., A. D. Brashaw and D. A. Thurman (1975): The potential for evolution of heavy metal tolerance in plants: III. The rapid evolution of copper tolerance in Agrostis stolonifera. Heredity 34: 165-187.
YE, T. Z., R.-C. YANG and F. C. YEH (2002): Population structure of a lodgepole pine (Pinus contorta) and jack pine ( $P$. banksiana) complex as revealed by random amplified polymorphic DNA. Genome 45: 530-540.

YeH, F., R. YANG and T. Boyle (1997): Popgene, version 1.32 edition, Software Microsoft Window-Based Freeware for Population Genetic Analysis. University of Alberta, Edmoton, Canada.

\title{
Genetic Variation in Early Growth Characteristics of Two Populations of Wild Service Tree (Sorbus torminalis (L.) Crantz) and Their Interrelationship
}

\author{
By K. Espahbodi ${ }^{1)}$, H. Mirzaie-Nodoushan ${ }^{2), *)}$, M. TABArI ${ }^{3)}$, M. AkBarinia ${ }^{3)}$, Y. Dehghan-Shuraki ${ }^{4)}$ and S. G. JALALI ${ }^{3)}$
}

(Received $10^{\text {th }}$ October 2007)

\begin{abstract}
This study was performed in order to compare two wild service tree populations (Sorbus torminalis (L.) Crantz) for their early growth and to find useful vegetative characteristics to be used in indirect selection of fast and tall growing trees of the species in the field. We used phenotypic and genotypic correlation coefficients estimated on data from 30 three-year old seedlings of each 40 randomly selected adult trees. Assuming genetic differences between the trees sampled, path analysis was performed on genotypic and phenotypic levels.

Results showed that plus trees of one of the sites may be used for clonal seed orchard establishment. But the other site is suggested as a better site for breeding purposes with more effective Sorbus population. Collar diameter had the strongest positive direct effect and strongest correlation with plant height at the phenotypic level. In contrast, lateral branches showed very weak direct effect but relatively strong total indirect effect on plant height. Path analysis on the genotypic correlation coefficients detected negative indirect effect between the characters. Collar diameter could be regarded as a good

1) Agriculture and Natural Resources Research Center of Mazandaran, Sary, Iran.

2) Forests and Rangelands Research Institute, Tehran, Iran.

$\left.{ }^{3}\right)$ Natural Resources Faculty, Tarbiat Modarres University, Noor, Iran.

4) Seed and Plant Certification and Registration Research Institute, Karaj, Iran.

*) Corresponding author: Hossein Mirzaie-Nodoushan. Forests and Rangelands Research Institute. Tehran-Karaj Highway, P.O. Box: 13185-116, Tehran, Iran. Tel.: 00982144195901-5. Fax: 00982144196575. E-Mail: nodoushan2003@yahoo.com
\end{abstract}

predictor of plant height because of its strong direct and indirect phenotypic and genotypic correlations. The use of recommended selection criteria is discussed.

Key words: Genotypic correlation, Half-Sib progenies, Path analysis, Vegetative characteristics.

\section{Introduction}

Sorbus torminalis (L.) Crantz is a tree species with high economical values (DEMESURE et al., 2000). Its natural distribution is rather large, from the north of Maghreb to the south of Denmark and from the east of Great Britain to the north of Iran (DEMESURE et al., 2000). Medicinal importance of the Sorbus species is also emphasized (TERMENTZI et al., 2006). The increasing concern on Sorbus species during last decades in European countries enables enlargement of genetic knowledge on them (BALIUCKAS et al., 2005). The species is scattered on the south edge of the Caspian Sea in forests of northern Iran along with beech (Fagus orientalis Lipsky.), Caucasian oak (Quercus castaneifolia C.A.M.), and hornbeam (Carpinus betulus L.). The best quality of wild service tree is found in northern and northeast aspects of the area on deep soil, where the species can grow as tall as 30 meter and exceed a diameter at breast height of 100 centimeter.

Genetic variation is the corner stone of all breeding strategies in forests reclamations, and is vastly considered in the literature. Genetic variability of various morphological and molecular aspects of the species is considered by numerous authors who have used various methods to characterize populations of the species (ANGELONE 